Original Article

\title{
Nutritional profile of kian marine worm from Kei islands Maluku as a potential high protein food resource
}

\author{
Siti Rahma Lestaluhu, Siti Nur Arifah, Umie Lestari, Sri Rahayu Lestari* \\ Department of Biology, Faculty of Mathematics and Natural Sciences, Universitas Negeri Malang, Jl. Semarang no.5, Malang 65145, East Java, \\ Indonesia
}

Abstract

The nutritional content of kian marine worm has never been reported. This study aimed to profile the nutritional content of worms from the Kei Islands, Maluku. Nutritional profiles were tested by proximate assays, atomic absorption spectroscopy (AAS), and High-Performance Liquid Chromatography (HPLC) of amino acids. The proximate analysis resulted in $71.16 \%$ of protein, $12.05 \%$ of water, $2.63 \%$ of carbohydrates, $2.21 \%$ of fat, $2.14 \%$ of crude fiber and $0.44 \%$ of ash. Mineral contents of Kian marine worm were $785.28 \mathrm{mg} / \mathrm{kg}$ potassium, $585.14 \mathrm{mg} / \mathrm{kg}$ magnesium, 180.98 $\mathrm{mg} / \mathrm{kg}$ calcium, $0.89 \mathrm{mg} / \mathrm{kg}$ sodium and $0.44 \mathrm{mg} / \mathrm{kg}$ phosphorus. Kian marine worms contained 9 essential amino acids and 11 essential amino acids with levels of essential amino acids up to $206.94 \mathrm{mg} / \mathrm{g}$ and non-essential amino acids was $233.21 \mathrm{mg} / \mathrm{g}$. Nutritional content in kian marine worms can be used as a potential high protein food resource.

Keywords: Potential food, Kei islands, kian marine worm, Maluku, protein

Received: 21 August 2020 Revised: 26 October 2020 Accepted: 30 October 2020

\section{Introduction}

The world's population has an estimated increase of $1.05 \%$ or 81 million people per year (United Nations, 2015). Indonesia as a developing country has a growth rate percentage every year up to $1.49 \%$ or $3.5-4$ million people (Badan Kependudukan dan Keluarga Berencana Nasional (BKKBN), 2016). The increase in Indonesia's population and globally has an impact on the ability to provide human necessities, especially in food production. This case has an effect on the lack of fulfillment of the basic nutritional requirements of inhabitants and caused several parts of society with low nutrient status. Indonesia as a developing country is trying to solve the problem of low nutrition or malnutrition, especially stunting issues in infants and toddlers (Hayati et al., 2012).

Maluku is one of Indonesia's regions with a low nutritional status with a high number of toddlers who are stunted according to WHO standards (Beal et al., 2018). Stunting is impairing growth in children, including body and brain growth due to long-term malnutrition, which resulted in children with shorter than healthy children at their age and slow response to cognitive achievement (Ni'mah \& Nadhiroh, 2015). Based on Basic Health Research in 2018, toddlers under five years old under stunting in Maluku province reached 31.4\% (Ministry of Health Republic of Indonesia, 2018). Based on the results of Nutrition Status Monitoring, the percentage of stunting in Maluku increased at children under five years

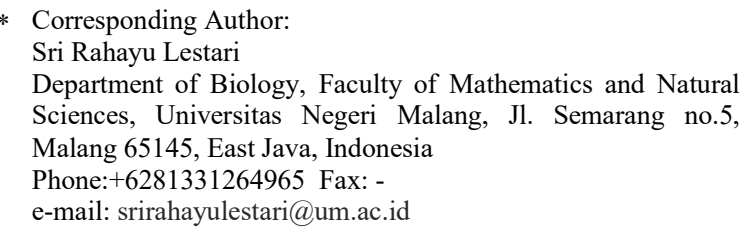

old from 29\% in 2016 and up to $30 \%$ in 2017 (Patty, 2019).

Improvements in nutritional status should be made by improving food intake. Food consumed by the people must be classified as functional foods, namely foods that benefit the health of the body (A. Pamungkas et al., 2014). Functional foods has have a composition of essential nutrients required by the body including sufficient macronutrients and micronutrients. Macronutrients are nutrients that are needed by the body in large amounts, namely of carbohydrates, protein and fat. Micronutrients are nutrients that needed by the body in small amounts, namely vitamins and minerals (Hans \& Jana, 2018). Protein is an important component on in improving nutritional status. Protein is closely related to growth and development process (Sediaoetama, 2012). Protein contains amino acids which have an essential role in metabolic processes such as the formation of neurotransmitters, purine/pyrimidine that arrange DNA chain (Rose, 2019), precursors for hormone formation, muscle activity (contraction and relaxation), regulating gene expression, etc (Wu, 2009). Several metabolic processes and biochemical pathways that lack or lose amino acid amine groups should be replaced through food consumption (Rose, 2019).

Indonesia has a high abundant abundance of biodiversity which contains a wide range of natural resources (Husen et al., 2017) especially in the marine field. The worm is not local wisdom, but consuming it as a meal can be classified as local wisdom. Based on the results of interviews with indigenous people of the Kei Islands, the existence of marine worm namely kian marine worms in the Kei Islands is very abundant, there are several places as habitats for these worms such as Wab Village, Hoat Sorbay District. The Wab's society has consumed ian marine worms with various cooking methods like smoke Kian marine worm (Ngabalin \& 
Talakua, 2017). However, the community in several Southeast Maluku Districts still lacks information about the benefits and the nutritional value of Kian marine worms.

The Kian marine worm is classified in the phylum of Nemertea. Marine worms as one of seafood has have higher nutrition compared with terrestrial organism especially it has superior source of various nutrients, such as protein, amino acids, fiber, vitamin and minerals (Hosomi et al., 2012). The benefit of consuming marine worms as local food in economic value is increasing the number of regional income because it will decrease dependency over imported foods (Rossi et al., 2017) and stimulate local economic development by creating jobs in some area (Coelho et al., 2018). Unfortunately, the beneficial of marine worms have not been used optimally yet in Indonesia. Moreover, the nutritional content of Kian marine worms from the Kei Islands has not been reported. The nutritional value of Kian marine worm can be used as information to develop a food candidate with high protein content.

\section{Methods}

\section{Collection and preparation sample}

Kian marine worm (Fig. 1) located in Uf beach were obtained by observing the presence of holes in the beach sand then digging these holes. $100 \mathrm{~g}$ of Kian marine worm were dried under the sunlight for 8 days, then oven for 3 days at $50^{\circ} \mathrm{C}$. Smashed using a blender to produce sea worm powder.

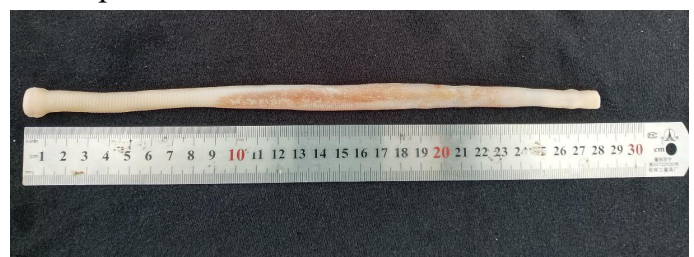

Figure 1. Kian marine worms from Kei island, Maluku

\section{Proximate test}

The proximate test includes testing the level of water, ash, crude protein, fat, crude fiber, and carbohydrate. The proximal test used proximate test protocol (Basu, 2013).

\section{Water level}

Measurement of water content used a gravimetric method. $5 \mathrm{~g}$ of kian marine worm powder were dried at $100^{\circ} \mathrm{C}$ for 4-7 hours or until in constant weight, then cooled in a desiccator, then weighed.

$$
\text { Water level }(\%)=\frac{(\text { initial weight-final weight })}{\text { final weight }} \times 100 \%
$$

\section{Ash level}

Measurement of ash levels used the gravimetric method. $5 \mathrm{~g}$ of kian marine worm was placed in a muffle furnace at $550^{\circ} \mathrm{C}$ for 24 hours until it become became white ash. The final weight was measured.

\section{Crude fiber level}

Crude fiber level test used the gravimetric method. 4 $\mathrm{g}$ of kian marine worm added with $50 \mathrm{ml} \mathrm{H}_{2} \mathrm{SO}_{4} 1.25 \%$, boiled then destructed for 30 minutes. Added $50 \mathrm{ml}$ of $3.25 \% \mathrm{NaOH}$ and boiled for 30 minutes. Filtered using Whatman paper, the precipitate result was washed with $\mathrm{H}_{2} \mathrm{SO}_{4} 1.25 \%$, hot water, and $96 \%$ ethanol, respectively. The weight of filter paper was measured as the initial weight of paper. Filter paper then dried at $105^{\circ} \mathrm{C}$, and weighed as filter paper with residue.

Crude fiber level $(\%)=($ weight of filter paper + residue $)-$ filter paper $\times 100 \%$ sample weight

\section{Protein level}

Protein levels test used acid-base titration method $0.25 \mathrm{~g}$ of Kian marine worm added with $0.25 \mathrm{~g}$ of selenium and $3 \mathrm{ml}$ of concentrated $\mathrm{H}_{2} \mathrm{SO}_{4}$, destructed for 1-2 hours at $400^{\circ} \mathrm{C}$ until the solution got clear. Added 50 $\mathrm{ml}$ of distilled water and $20 \mathrm{ml}$ of $\mathrm{NaOH} 40 \%$, distilled at $100^{\circ} \mathrm{C}$. Add $10 \mathrm{ml}$ of $2 \% \mathrm{H}_{3} \mathrm{BO}_{3}$ and 2 drops of bromocresol green-methyl red into distillate. Titrated with $\mathrm{HCl} 0.1 \mathrm{~N}$.

\section{Lipid level}

Lipid content test used gravimetric extraction method. This test used a fat sleeve, soxhlet tube extractor chamber and benzene as a solvent. The result then dried in an oven at $105^{\circ} \mathrm{C}$ and then the weight was measured.

$$
\text { Lipid level }(\%)=\frac{\text { lipid weight }}{\text { sample weight }} \times 100 \%
$$

\section{Carbohydrate level}

Carbohydrate level calculation $(\%)=100 \%$ - (water level + ash level + protein level + lipid level + crude fiber level)

\section{Mineral levels test}

Mineral assay used a spectrophotometric method. Measurements used atomic absorption spectroscopy (AAS) (Kryazhov et al., 2014) at $421.4 \mathrm{~nm}$ of wavelength.

Mineral level $(\mathrm{ppm})=\frac{\text { absorbance xvolume }}{\text { regression slope } \mathrm{x} \text { sample weight }}$

\section{Amino acid level test}

Amino acid level was tested using the HighPerformance Liquid Chromatography (HPLC) method. $50 \mu 1$ of the prepared sample was injected into the HPLC column at $40^{\circ} \mathrm{C}$, Shim-pack VP ODS $5 \mu \mathrm{L} 150 \times 4.6 \mathrm{~mm}$, flow rate $1 \mathrm{ml} /$ minute, acetonitrile $60 \%$ as mobile phase, $0.1 \mathrm{M}$ phosphate buffer, and wavelength at $450 \mathrm{~nm}$. The amino acid level was shown in $\mathrm{mg} / \mathrm{g}$ dry sample.

\section{Data analysis}

Data were analyzed descriptively to determine the nutrition content of Kian marine worm as potential high protein food resources.

$$
\text { Ash level }(\%)=\frac{\text { final weight }}{\text { initial weight }} \times 100 \%
$$




\section{Results}

Based on the proximate test (Tab. 1), Kian marine worm contained high level of protein. Protein level in Kian marine worm reached up to $71.16 \%$. The water level was $12.05 \%$ of the body's dry weight. Kian marine worms also contained fat, crude fiber, and carbohydrates with the percentage $2.21 \%, 2.14 \%$, and $2.63 \%$, respectively.

Table 1. Nutritional information of Kian marine sea worm based on proximate test

\begin{tabular}{lc}
\hline Proximate composition & Percentage (\%) \\
\hline Water & 12,05 \\
Ash & 0,44 \\
Protein & 71,16 \\
Lipid & 2,21 \\
Crude fiber & 2,14 \\
Carbohydrate & 2,63 \\
\hline
\end{tabular}

Based on HPLC analysis of 20 amino acids, the essential amino acid levels of Kian marine worm reached $206.94 \mathrm{mg} / \mathrm{g}$ and levels of non-essential amino acids reached $233.21 \mathrm{mg} / \mathrm{g}$ (Tab. 2). Amino acids are important components for the body and are involved in various metabolic processes in the body.

Table 2. Amino acid profile of Kian marine sea worm based on HPLC

\begin{tabular}{lc}
\hline Amino acid & Level (mg/g) \\
\hline Threonine (Thr) & 14.20 \\
Valine (Val) & 39.87 \\
Methionine (Met) & 12.20 \\
Isoleucine (Ile) & 21.50 \\
Leucine (Leu) & 30.14 \\
Phenylalanine (Phe) & 15.90 \\
Histidine (His) & 29.32 \\
Lysine (Lys) & 40.74 \\
Tryptophan (Trp) & 3.07 \\
Eessential amino acid & 206.94 \\
Asparagine (Asn) & 3.52 \\
Serin (Ser) & 17.13 \\
Glutamic acid (Glu) & 55.77 \\
Proline (Pro) & 14.24 \\
Glycine (Gly) & 17.86 \\
Alanine (Ala) & 24.45 \\
Tyrosine (Tyr) & 20.03 \\
Argginine (Arg) & 27.09 \\
Aspartic acid (Asp) & 45.73 \\
Glutamine (Gln) & 3.19 \\
Cysteine (Cys) & 4.20 \\
Enon-essential amino acid & 233.21 \\
\hline
\end{tabular}

Furthermore, mineral tests on Kian marine worms showed high potassium (K) level (Tab. 3). The potassium level of Kian marine worms was 785.28 $\mathrm{mg} / \mathrm{kg}$. Kian marine worms contained calcium (Ca) level at $180.98 \mathrm{mg} / \mathrm{kg}$, magnesium $(\mathrm{Mg})$ at $585.14 \mathrm{mg} / \mathrm{kg}$, sodium $(\mathrm{Na})$ at $0.89 \mathrm{mg} / \mathrm{kg}$, and phosphorus $(\mathrm{P})$ at 0.44 $\mathrm{mg} / \mathrm{kg}$.

Table 3. Mineral level in Kian marine sea worm

\begin{tabular}{lc}
\hline Minerals & Level $(\mathbf{m g} / \mathbf{k g})$ \\
\hline Calcium $(\mathrm{Ca})$ & 180,98 \\
Potassium $(\mathrm{K})$ & 785,28 \\
Magnesium $(\mathrm{Mg})$ & 585,14 \\
Natrium $(\mathrm{Na})$ & 0,89 \\
Phosphorus $(\mathrm{P})$ & 0,44 \\
\hline
\end{tabular}

\section{Discussion}

Kian marine worm, originaly from the Kei Islands, Southeast Maluku Regency is one of Maluku local wisdom. The existence of Kian marine worms in the Kei Islands is very abundant. Based on a proximate test, Kian marine worm contained $71.16 \%$ of protein. Protein level in Kian marine worm was higher than in BangkaBelitung worm (Xenosiphon sp.) with $38.72 \%$ protein (Fakhrurrozi, 2011), wawo worm (Palola sp.) from Ambon with $54.72 \%$ protein (J. Pamungkas, 2015), and sea worms from Kendari, Siphonosoma australe-australe with 56.35\% protein (Nurhikma et al., 2017). Protein is a crucial nutrient in the regeneration of cells and tissues (Erviani \& Arif, 2017). The implication of lack protein is increasing of susceptibility over disease and causes growth disorder in children namely stunting (Raiten \& Bremer, 2020). Proteins also have an important role in the formation of biomolecules, such as enzymes (Alberts et al., 2002). Protein is closely related to the immune system, low protein intake causes on a decrease of immune system (Akram et al., 2020). The water level in Kian marine worms was lower than in wawo worms (Palola sp.) with $10.71 \%$ water level (J. Pamungkas, 2015 ) and Kendari sea worms $13.69 \%$ water level (Nurhikma et al., 2017). The high protein level in Kian marine worm caused low water level in the worm's body (Adawyah, 2007; Yuarni et al., 2018).

High-quality of protein is determined by the type and proportion of amino acids. Proteins contained all types of amino acids in portions suitable for growth (Purwaningsih et al., 2013). If one amino acid is unavailable, either essential or non-essential, all the remaining amino acids cannot be used and undergo catabolism. This has an impact on the negative nitrogen balance (Engelking, 2015). Essential amino acids cannot be synthesized in the human body, although it plays an important role. As a result, they must be present in daily food. The essential amino acids for adults consist of lysine, leucine, isoleucine, threonine, methionine, valine, phenylalanine, and tryptophan, while the essential amino acids for children are added with arginine, glycine, and histidine. Non-essential amino acids consist of aspartic acid, glutamic acid, alanine, asparagine, cysteine, glycine, proline, tyrosine, serine, and glutamine (Engelking, 2015).

Essential amino acids have important functions for the body. Lysine and leucine are basic properties for antibodies, maintain tissue function, and improve the immune system ( $\mathrm{Li}$ et al., 2007). Isoleucine is one of branched chain amino acid which play a major role in enhancing glucose consumption and utilization by upregulating intestinal and muscular glucose transporters (Zhang et al., 2017). Threonine is widely used for poultry feed in case to optimalization of growth state and intestinal development morphology (Najafi et al., 2017). Feng et al. (2013) also reported that threonine improved growth, digestive and absorption capacity, and enterocyte proliferation and differentiation in juvenile Jian carp. Threonine might be had an essential role on growth and development process in the body. Methionine playsa role in metabolic processes, especially 
lipid metabolism, activation of endogenous antioxidants in the form of methionine sulfoxide reductase. Methionine also plays an important role in reducing free radicals and oxidative stress by increasing glutathione peroxidase (GPx) biosynthesis (Martínez et al., 2017). Valine is an amino acid with a branched-chain that is very important for metabolism and coordination of muscle tissue and nitrogen balance in the body (Bifari \& Nisoli, 2017). Phenylalanine has a function as an antidepressant. Phenylalanine plays a role in the formation of neurotransmitters such as dopamine, nor-epinephrine, and epinephrine (Akram et al., 2020). The amino acid threonine acts as an immunostimulant by increasing the thymus gland (Abbasi et al., 2014). The regulation of tryptophan is very critical for the maintenance systemic homeostasis related with its integrates essential pathways involved in nutrient sensing, metabolic stress response, and especially immune response (Gostner et al., 2020). Arginine plays in critical role on insulin secretion, growth hormone (Holecek \& Sispera, 2016), and also prevent and treat various metabolic diseases such as cardiovascular disease, erectile dysfunction, and gastric hyperacidity (Gad, 2010).

The percentage of lipid levels in Kian marine worm was $2.21 \%$ and higher than lipid level of Kekuak (Xenosiphon sp.) with only 1.78\% (Fakhrurrozi, 2011). Lipid content in Kian marine worms is different along with differences in nutrition in the habitat (Nurhikma et al., 2017; Silaban \& Silaban, 2019). Marine lipid is very essential for health due to its function to treat various disease. Méndez et al. (2017) reported $\omega-3$ polyunsaturated fatty acids (PUFAs), eicosapentaenoic (EPA) and docosahexaenoic (DHA) which were contained in marine lipids have been linked to treat cardiovascular diseases dan type 2 diabetes mellitus (T2DM). Kian marine worms also have crude fiber level 2.14\%, meanwhile Kekuak (Xenosiphon sp.) only 1.06\% of crude fiber (Fakhrurrozi, 2011). Carbohydrate level of Kian marine worm was $2.63 \%$ lower than Siphonosoma austral-australe sea worm with $5.06 \%$ carbohydrate level (Nurhikma et al., 2017). Low-carbohydrate diet could be used to improve glucose intake and expenditure in the body thus prevent various disease related with glucose levels such as diabetes (Eiswirth et al., 2018).

Potassium and sodium play an important role in maintaining fluid balance and maintaining body health (Pohl et al., 2013). Potassium also plays a role in nerve transmission of muscle relaxation. Lack of potassium can cause various diseases and increase oxidative stress in the body (Udensi \& Tchounwou, 2017). The magnesium content in kian worms was $585.14 \mathrm{mg} / \mathrm{kg}$. Magnesium is an essential mineral for the body because it is a co-factor for more than 300 enzymes that regulate various biochemical activities in the body. About $60 \%$ of total magnesium is stored in bones. Deficiency of magnesium can lead to various diseases, especially those related to bones and teeth for example osteoporosis (Castiglioni et al., 2013). Hermawan et al. (2015) stated that substrate significantly affects the ash content of marine worms, the sand substrate contains various minerals. Marine worms are a deposit feeder so they contain a lot of minerals in their bodies because they eat all the sediment in the substrate.

In conclusion, kian marine worm contained high protein level, essential minerals, and both of amino acids essential and non-essential that play an important role in biochemical processes in the body. Kian marine worm can be used as a potential high protein food resource to completing basic nutrition in the body.

\section{Acknowledgement}

We would like to thank to Ministry of Research, Technology, and Higher Education of Republic Indonesia with grant number 10.3.42/UN.32.14.1/2020 for support this research.

\section{References}

Abbasi, Ma, Ah Mahdavi, Ah Samie, and R. Jahanian. 2014. "Effects of Different Levels of Dietary Crude Protein and Threonine on Performance, Humoral Immune Responses and Intestinal Morphology of Broiler Chicks." Revista Brasileira de Ciência Avicola 16(1):35-44. doi: 10.1590/S1516635X2014000100005.

Adawyah, Rabiatul. 2007. Pengolahan dan pengawetan ikan. Jakarta: Bumi Aksara.

Akram, Muhammad, Muhammad Daniyal, Aatiqa Ali, Rida Zainab, Syed Muhammad Ali Shah, Naveed Munir, and Imtiaz Mahmood Tahir. 2020. "Role of Phenylalanine and Its Metabolites in Health and Neurological Disorders." Synucleins - Biochemistry and Role in Diseases. doi: 10.5772/intechopen.83648.

Alberts, Bruce, Alexander Johnson, Julian Lewis, Martin Raff, Keith Roberts, and Peter Walter. 2002. "Protein Function." Molecular Biology of the Cell. 4th Edition.

Badan Kependudukan dan Keluarga Berencana Nasional (BKKBN). 2016. "Laju Pertumbuhan Penduduk 4 Juta Per Tahun." $\begin{array}{lll}\text { Retrieved July } & 13, & 2020\end{array}$ (https://www.bkkbn.go.id/detailpost/laju-pertumbuhanpenduduk-4-juta-per-tahun).

Basu, Prabir. 2013. “Chapter 13 - Analytical Techniques.” Pp. 439-55 in Biomass Gasification, Pyrolysis and Torrefaction (Second Edition), edited by P. Basu. Boston: Academic Press.

Beal, Ty, Alison Tumilowicz, Aang Sutrisna, Doddy Izwardy, and Lynnette M. Neufeld. 2018. "A Review of Child Stunting Determinants in Indonesia." Maternal \& Child Nutrition 14(4). doi: $10.1111 / \mathrm{mcn} .12617$.

Bifari, Francesco, and Enzo Nisoli. 2017. "Branched-chain Amino Acids Differently Modulate Catabolic and Anabolic States in Mammals: A Pharmacological Point of View." British Journal of Pharmacology 174(11):1366-77. doi: 10.1111/bph.13624.

Castiglioni, Sara, Alessandra Cazzaniga, Walter Albisetti, and Jeanette A. M. Maier. 2013. "Magnesium and Osteoporosis: Current State of Knowledge and Future Research Directions." Nutrients 5(8):3022-33. doi: 10.3390/nu5083022.

Coelho, Fábio Cunha, Enilce Maria Coelho, Monika Egerer, Fábio Cunha Coelho, Enilce Maria Coelho, and Monika Egerer. 2018. "Local Food: Benefits and Failings Due to Modern Agriculture." Scientia Agricola 75(1):84-94. doi: 10.1590/1678-992x-2015-0439.

Eiswirth, Mirjam, Ewan Clark, and Michael Diamond. 2018. "Low Carbohydrate Diet and Improved Glycaemic Control in a Patient with Type One Diabetes." Endocrinology, Diabetes \& Metabolism Case Reports 2018. doi: 10.1530/EDM-18-0002.

Engelking, Larry R. 2015. "Chapter 3 - Amino Acid Modifications.” Pp 12-17 in Textbook of Veterinary Physiological Chemistry (Third Edition), edited by L. R. Engelking. Boston: Academic Press. 
Erviani, Andi Evi, and Abdur Rahman Arif. 2017. "Rendemen Analysis and Phytochemical Screening of Perinereis Aibuhitensis Extracts." International Journal of Current Research and Academic Review 5(11):25-29. doi: 10.20546/ijcrar.2017.511.005.

Fakhrurrozi, Yulian. 2011. "Studi Etnobiologi, Etnoteknologi Dan Pemanfaatan Kekuak (Xenosiphon Sp.) Oleh Masyarakat Di Kepulauan Bangka-Belitung.” Disertation, Institut Pertanian Bogor (IPB), Bogor.

Feng, Lin, Yan Peng, Pei Wu, Kai Hu, Wei-Dan Jiang, Yang Liu, Jun Jiang, Shu-Hong Li, and Xiao-Qiu Zhou. 2013. "Threonine Affects Intestinal Function, Protein Synthesis and Gene Expression of TOR in Jian Carp (Cyprinus Carpio Var. Jian)." PLOS ONE 8(7):e69974. doi: 10.1371/journal.pone.0069974.

Gad, Mohamed Z. 2010. "Anti-Aging Effects of 1-Arginine." Journal of Advanced Research 1(3):169-77. doi: 10.1016/j.jare.2010.05.001.

Gostner, Johanna M., Simon Geisler, Marlies Stonig, Lisa Mair, Barbara Sperner-Unterweger, and Dietmar Fuchs. 2020. "Tryptophan Metabolism and Related Pathways in Psychoneuroimmunology: The Impact of Nutrition and Lifestyle." Neuropsychobiology 79(1-2):89-99. doi: $10.1159 / 000496293$.

Hans, K. B., and Tinz Jana. 2018. "Micronutrients in the Life Cycle: Requirements and Sufficient Supply." NFS Journal 11:1-11. doi: 10.1016/j.nfs.2018.03.001.

Hayati, Aslis Wirda, Hardinsyah Hardinsyah, Fasli Jalal, Siti Madanijah, and Dodik Briawan. 2012. "Pola Konsumsi Pangan Dan Asupan Energi Dan Zat Gizi Anak Stunting Dan Tidak Stunting 0-23 Bulan.” Jurnal Gizi Dan Pangan 7(2):7380. doi: 10.25182/jgp.2012.7.2.73-80.

Hermawan, Dodi, Saifullah, and Dana Herdiyana. 2015. "The Effect of Different Substrat of Culture of Nereis sp." Jurnal Perikanan dan Kelautan 5(1):41. doi: 10.33512/jpk.v5i1.277.

Holecek, Milan, and Ludek Sispera. 2016. "Effects of Arginine Supplementation on Amino Acid Profiles in Blood and Tissues in Fed and Overnight-Fasted Rats." Nutrients 8(4). doi: $10.3390 /$ nu8040206.

Hosomi, Ryota, Munehiro Yoshida, and Kenji Fukunaga. 2012. "Seafood Consumption and Components for Health." Global Journal of Health Science 4(3):72-86. doi: 10.5539/gjhs.v4n3p72.

Husen, Saikhu Akhmad, Dwi Winarni, Firas Khaleyla, and Septian Hary Kalqutny. 2017. "Activity Test of Various Mangosteen (Garcinia Mangostana) Pericarp Extract Fractions to Decrease Fasting Blood Cholesterol Levels and Lipid Peroxidation Activity in Diabetic Mice." Journal of Biological Researches 22(1):13-17. doi: 10.23869/bphjbr.22.1.20163.

Kryazhov, A., S. Panova, N. Kolpakova, and A. Pshenichkin. 2014. "Determination of $\mathrm{Au}, \mathrm{Pb}, \mathrm{Ni}$ and $\mathrm{Co}$ in Mineral Raw Materials by Atomic Absorption Spectroscopy with Graphite Furnace." Procedia Chemistry 10:437-40. doi: 10.1016/j.proche.2014.10.073.

Li, Peng, Yu-Long Yin, Defa Li, Sung Woo Kim, and Guoyao Wu. 2007. "Amino Acids and Immune Function." British Journal of Nutrition 98(2):237-52. doi: 10.1017/S000711450769936X.

Martínez, Yordan, Xue Li, Gang Liu, Peng Bin, Wenxin Yan, Dairon Más, Manuel Valdivié, Chien-An Andy Hu, Wenkai Ren, and Yulong Yin. 2017. "The Role of Methionine on Metabolism, Oxidative Stress, and Diseases." Amino Acids 49(12):2091-98 doi: 10.1007/s00726-017-2494-2.

Méndez, Lucía, Gabriel Dasilva, Nùria Taltavull, Marta Romeu, and Isabel Medina. 2017. "Marine Lipids on Cardiovascular Diseases and Other Chronic Diseases Induced by Diet: An Insight Provided by Proteomics and Lipidomics." Marine Drugs 15(8). doi: $10.3390 / \mathrm{md} 15080258$.

Ministry of Health Republic of Indonesia. 2018. Hasil Utama Riset Kesehatan Dasar (Riskesdas) 2018. Jakarta: Badan Penelitian dan Pengembangan Kesehatan.

Najafi, R., R. Ahmar, and Gn Tazehkand. 2017. "Effect of Different Dietary Threonine Levels on Optimal Growth Performance and Intestinal Morphology in 1-14 Days Old Ross 308 Broilers." Revista Brasileira de Ciência Avícola 19(spe):5966. doi: 10.1590/1806-9061-2016-0327.

Ngabalin, Daniel, and Eygner Gerald Talakua. 2017. "Usaha Pengolahan Ikan Dan Cacing Laut (Kian) Asap Di Ohoi Wab, Kecamatan Hoat Sorbay." Agrokreatif Jurnal Ilmiah
Pengabdian Kepada Masyarakat 3(1):52. doi: 10.29244/agrokreatif.3.1.52-59.

Ni'mah, Khoirun, and Siti Rahayu Nadhiroh. 2015. "Faktor yang Berhubungan dengan Kejadian Stunting pada Balita." Media Gizi Indonesia 10(1):13-19.

Nurhikma, Nurhikma, Tati Nurhayati, and Sri Purwaningsih. 2017. "Amino Acid, Fatty Acid, and Mineral Content of Marine Worm From South East Sulawesi." Jurnal Pengolahan Hasil Perikanan Indonesia 20(1):36. doi: 10.17844/jphpi.v20i1.16396.

Pamungkas, Anggar, Ahmad Sulaeman, and Katrin Roosita. 2014. "Pengembangan Produk Minuman Daun Hantap (Sterculia Oblongata R. Brown) Sebagai Alternatif Pangan Fungsional." Jurnal Gizi Dan Pangan 9(3). doi: 10.25182/jgp.2014.9.3.\%p.

Pamungkas, Joko. 2015. "Species Richness and Macronutrient Content of Wawo Worms (Polychaeta, Annelida) from Ambonese Waters, Maluku, Indonesia.” Biodiversity Data Journal (3). doi: 10.3897/BDJ.3.e4251

Patty, Rahmat Rahman. 2019. “Angka Stunting Di Maluku Tinggi, Ini Upaya Pemberantasannya." Kompas, August, Regional Kompas.

Pohl, Hana R., John S. Wheeler, and H. Edward Murray. 2013. "Sodium and Potassium in Health and Disease." Pp. 29-47 in Interrelations between Essential Metal Ions and Human Diseases. Vol. 13, Metal Ions in Life Sciences. Dordrecht: Springer Netherlands.

Purwaningsih, Sri, Ella Salamah, and Gian P. Apriyana. 2013. "Profil Protein dan Asam Amino Keong Ipong-Ipong (Fasciolaria salmo) pada Pengolahan yang Berbeda." Jurnal Gizi dan Pangan 8(1):77. doi: 10.25182/jgp.2013.8.1.77-82.

Raiten, Daniel J., and Andrew A. Bremer. 2020. "Exploring the Nutritional Ecology of Stunting: New Approaches to an Old Problem." Nutrients 12(2):371. doi: 10.3390/nu12020371.

Rose, Adam J. 2019. "Amino Acid Nutrition and Metabolism in Health and Disease." Nutrients 11(11). doi: 10.3390/nu11112623.

Rossi, James D., Thomas G. Johnson, and Mary Hendrickson. 2017. "The Economic Impacts of Local and Conventional Food Sales." Journal of Agricultural and Applied Economics 49(4):555-70. doi: 10.1017/aae.2017.14.

Sediaoetama, Achmad Djaeni. 2012. Ilmu Gizi Untuk Mahasiswa Dan Propesi Jil.1. Jakarta: Dian Rakyat.

Silaban, Bernita br, and Rosita Silaban. 2019. Cacing Kacang (Sipuncula): Kajian Biologi, Ekologi, Penangkapan Dan Pemanfaatan. Deepublish.

Udensi, Udensi K., and Paul B. Tchounwou. 2017. "Potassium Homeostasis, Oxidative Stress, and Human Disease." International Journal of Clinical and Experimental Physiology 4(3):111-22. doi: 10.4103/ijcep.ijcep 43 17.

United Nations. 2015. "Population." Retrieved July 13, 2020 (https://www.un.org/en/sections/issuesdepth/population/index.html).

Wu, Guoyao. 2009. "Amino Acids: Metabolism, Functions, and Nutrition." Amino Acids 37(1):1-17. doi: 10.1007/s00726009-0269-0.

Yuarni, Desi, Kadirman Kadirman, and Jamaluddin P. Jamaluddin P. 2018. "Laju Perubahan Kadar Air, Kadar Protein dan Uji Organoleptik Ikan Lele Asin Menggunakan Alat Pengering Kabinet (Cabinet Dryer) dengan Suhu Terkontrol." Jurnal Pendidikan Teknologi Pertanian 1(1):12. doi: 10.26858/jptp.v1i1.5139.

Zhang, Shihai, Xiangfang Zeng, Man Ren, Xiangbing Mao, and Shiyan Qiao. 2017. "Novel Metabolic and Physiological Functions of Branched Chain Amino Acids: A Review." Journal of Animal Science and Biotechnology 8. doi: 10.1186/s40104-016-0139$\mathrm{z}$. 